Doğan, B., Yıldırım, K., Çermik, H. ve Ateş, S. (2018). Okuma çemberleri: Niçin ve nasıl? Örnek bir uygulama. Ana Dili Eğitimi Dergisi, 6(3), 747-765.

$\begin{gathered}\text { Ana Dili Eğitimi Dergisi } \\ \text { Journal of Mother Tongue Education } \\ \text { www.anadiliegitimi.com }\end{gathered}$
Geliş/Received: 29.05 .2018 Kabul/Accepted:21.06.2018

\title{
Okuma Çemberleri: Niçin ve Nasıl? Örnek Bir Uygulama*
}

\begin{abstract}
Birsen DOĞAN ${ }^{* *}$
KasIm YILDIRIM***

Hülya ÇERMiK ${ }^{* * * *}$

Seyit ATEŞ $S^{* * * *}$

Öz

Okuma çemberleri, aynı öykü, şiir ya da kitabı okumak için bir araya gelen öğrencilerin oluşturdukları gruplardır. Bu gruplarda öğrenciler, okuduklarını tartışmakta ve paylaşmaktadırlar. Gruplarda üstlendikleri rollerin gereği olarak öğrenciler, okuma çemberlerinde pek çok etkinlik yapmaktadırlar. Bu roller, temel ve seçimlik roller olmak üzere iki grupta toplanabilir. Temel roller, sorgulayıcı, bağ kurucu, okuma aydınlatıcısı, ressamdır. Seçimlik roller ise özetleyici, sözcük avcısı, hareket izcisi, karakter çözümleyici ve tahmin edici gibi rollerdir. Her öğrenci bir rol almak zorundadır. Rollerin gereği olarak yapılan işler, öğrencilerin bilişsel, duyuşsal ve sosyal yönlerinin gelişimini sağlamaktadır. Yapılan her okuma çemberinde öğrenciler ve roller farklılaşmaktadır. Böylece farklı rolleri deneyimleyen öğrenciler okuma çalışmalarından üst düzeyde verim elde edebilmektedirler. Okuma çemberlerinin nasıl yürütüldüğüne ilişkin adım adım sunulan örnek bir uygulamanın, sınıflarında öğrenci merkezli yöntemleri kullanmak isteyen öğretmenlere katkılar sunması beklenmektedir.
\end{abstract}

Anahtar Kelimeler: Okuma çemberleri, okuma becerileri, öğrenci, öğretmen

\section{Literature Circles: Why and How? An Example of Implementation}

\begin{abstract}
Literature circles are groups formed by students who get together to read the same story, poem or book. In these groups, students discuss and share what they have read. As required by the roles they assume in groups, students perform many activities in literature circles. These roles may be divided into two groups as main and optional roles. The main roles are questioner, connector, literary luminary, and illustrator. The optional roles are roles such as summarizer, vocabulary enricher (word wizard), scene setter, character sketcher, and predictor. Every student has to assume a role. Literature circle activities that are done in classes contribute to students' cognitive, affective and social development. In each literature circle, students and their roles differ. Thus, students who assume various roles in literature circles are able to benefit highly from these reading activities. A step-by-step example of how literature circles are implemented in classes is given to contribute to teachers who want to use student-centered methods in their classrooms.
\end{abstract}

Keywords: Literature circles, Reading skills, Student, Teacher

\footnotetext{
* Bu çalışma TÜBITAK 1001 117K108 nolu "Bir adım da biz atalım: Okuyalım, paylaşalım, okutalım ve yayalım” projesi kapsamında desteklenmektedir.

** Doç. Dr., Pamukkale Üniversitesi , Eğitim Fakültesi, Temel Eğitim Bölümü, Denizli, bdogan@pau.edu.tr

*** Doç. Dr., Muğla Sıtkı Koçman Üniversitesi, Eğitim Fakültesi, Temel Eğitim Bölümü, Muğla, kasimyildirim@mu.edu.tr. Bu araştırmacı TÜBiTAK 2219 Yurtdışı Doktora Sonrası Araştırma Bursu kapsamında desteklenmektedir.

**** Doç. Dr., Pamukkale Üniversitesi , Eğitim Fakültesi, Temel Eğitim Bölümü, Denizli, hcermek@pau.edu.tr ***** Doç. Dr., Gazi Üniversitesi, Gazi Eğitim Fakültesi, Temel Eğitim Bölümü, Ankara, seyitates@gazi.edu.tr
} 


\section{Giriş}

Çağdaş yaklaşımlar ışığında hazırlanan programları sınıfında uygulamak isteyen öğretmen sıklıkla kendine şu soruları sorar: "Öğrencilerimin okuduğunu anlama düzeylerini, eleştirel okuma becerilerini nasıl geliştirebilirim, hangi stratejileri kullanırsam öğrencilerim okuduklarını daha iyi anlar?" Bu sorulara cevap arayarak okumanın bilişsel olan yönünü geliştirmeye çalışırken, okumanın duyuşsal yönünü geliştirmek için de "Öğrencilerimde okuma ilgisi nasıl oluşturabilirim, severek okumalarını nasıl sağlayabilirim, okumaya karşı olumlu tutum nasıl geliştirebilirim?" soruları üzerinde düşünür. Öte yandan okumanın bir de sosyal yönü vardır. "Öğrencilerimin iş birliği içinde çalışmaları, birbirlerini etkili bir şekilde dinlemeleri, birbirlerinin düşüncelerine saygı duyarak tartışmaları ve birbirlerinden öğrenebilmeleri için ne yapabilirim?" gibi sorulara cevap arayarak ise sosyal yönünü geliştirmeye çalışır. Bütün bunları gerçekleştirecek sihirli bir değnek olmasa da alan yazında öğretmenlerin tüm bu sorularına cevap verebilecek; bilişsel, duyuşsal ve sosyal yönlerden öğrencilerinin gelişimine katkı sağlayabilecek farklı yöntemler bulunmaktadır. Bu yöntemlerden biri olan 'okuma çemberleri' kullanılarak öğrencilerin hem bilişsel hem duyuşsal hem de sosyal yönden çok yönlü gelişimlerine katkıda bulunulabilir.

\section{Okuma Çemberleri Nedir?}

Okuma çemberleri, aynı öykü, şiir, makale ya da kitapları okumayı seçen öğrencilerin bir araya gelerek küçük gruplar oluşturması ve bu gruplarda okunanların tartışılması ve paylaşılması etkinliğidir (Daniels, 2002). Okuma çemberleri, öğretmen ya da metin merkezli değildir, öğrenci merkezlidir. Öğrenci bakış açısı ve sorularına dayalı olarak işler. Kalıplaşmış belli kurallara göre yürütülmez, esnek ve akıcıdır. Ancak kuralların olmaması sürecin kontrol edilmediği ya da sadece yapılandırılmamış konuşma toplantıları şeklinde yürütüldüğü anlamına gelmez. Aksine okuma çemberleri öğrencilerin bağımsız olacakları ve sorumluluk alacakları şekilde yapılandırılan gruplardır. Gruplar öğrenci yeteneklerine göre değil, öğrencilerin ilgi duydukları kitap seçimine göre oluşturulur. Öğrenciler bu gruplarda liderlik rolü üstlenebilecekleri gibi grup içinde farklı sorumluluklar ve değişik roller de alabilirler (Schoonmaker, 2014).

\section{Niçin Okuma Çemberleri?}

Öğrencilerin üst düzey zihinsel becerilerini geliştirmede, sosyal etkileşimlerin rolü önemlidir. Çünkü sosyal etkileşim, öğrencilerin etkinliklerde birlikte çalışmalarına ve yeni bilgiyi kendileri için anlamlı hale getirmelerine yardımcı olur. Daniels $(1994,2002)$ tarafından da ifade edildiği gibi okuma çemberlerinde öğrenciler bir araya gelerek seçilmiş olan şiiri, makaleyi, kitabı birlikte tartışarak öğrenirler. Her bir grup kendine verilen kısmı çalışırken grup üyeleri çeşitli notlar alarak yapılacak tartışmaya katkı sağlar. Herkes gruba geldiğinde edinmiş olduğu yeni fikirleri grup üyeleri ile paylaşır. 


\section{Okuma Çemberleri: Niçin ve Nasıl? Örnek Bir Uygulama}

Her bir grup okunan materyalle ilgili olarak bir okuma ve toplantı programını takip eder. Kitap tamamlandığında çemberdeki üyeler okumaları ile ilgili önemli noktaları başkaları ile de paylaşırlar. Yeni gruplarla ve yeni çemberlerle bu süreç yeni okumalar için devam eder. Özellikle okuma çemberleri uygulamaları içerisinde öğrenciler tarafından üstlenilen roller, öğrencilerin öğrenme sürecini öğretmen merkezli yapıdan öğrenci merkezli yapıya taşımalarına katkı sağlar. Yine bu roller öğrencilerin iş birlikli bir şekilde çalışmalarına imkân verir.

Raphel'e (1997, akt. Pambianchi, 2017) göre okuma çemberleri öğretmene öğrencilerin okuma, yazma ve eleştirel düşünebilme becerilerine yardımcı olması noktasında önemli fırsatlar sağlamaktadır. Öğrenme önceden bilinenlerle yeni bilginin bir araya getirilerek işlendiği bir süreç olarak ele alındığında (Lyons ve Pinnell, 2001), sürecin düşünce üretimiyle sonlandığını söylemek mümkündür. Düşünce üretimi kadar bu düşüncelerin paylaşımı da oldukça önemlidir. Bu noktada okuma çemberleri düşünce üretimini bir adım öteye taşıyarak öğrencilerin düşüncelerini ifade edebilecekleri bir araç olarak da hizmet etmektedir (Brabham ve Villaume, 2000). Konuşma, tartışma, çizme ya da yazma yoluyla gerçekleşen ifade ve paylaşım süreci öğrencilerin okuma becerilerinin yanı sıra diğer dil ve üst düzey düşünme becerilerinin gelişimine de katkı sağlamaktadır. Daha zor metinlerle sınıf tartışmalarının oluşturulması, öğrencilerin derinlemesine anlamalarına yardımcı olmakla kalmayıp aynı zamanda özgün yazılar ortaya koymalarına katkı sağlamaktadır. Pearson, Cervetti ve Tilson (2008) anlama sürecini, etkilenme ve tepki verme eylemi olarak görmektedir. Öğrenciler okuma çemberlerinde sürekli düşünür ve etkileşimde bulunurlar. Çalışılan materyal hakkında okumalar ve etkileşimler doğrultusunda daha zengin bir anlam geliştirirler. Okuma çemberleri sayesinde öğrencilerin okuduklarına ilişkin farkındalıkları artar ve gerektiğinde okunanı daha fazla açıklığa kavuşturmak için rahatlıkla arayış içerisine girebilirler. Okuma çemberleri, yapılandırılmış tartışmalar yoluyla öğrencilerin okuduklarının derinlemesine anlamlandırılmasında öğrencilere katkılar sunar (Campbell Hill, 2010).

Okuma çemberleri öğrencilerin kendilerine uygun olan kitabı seçmelerine izin vermesi açısından da farklılaşmaktadır (Tomlinson ve Strickland, 2005). Zira araştırmacılar okunacak kitap ve zaman konusunda öğrencilerin tercih yapmalarının ve inisiyatif sahibi olmalarının önemine işaret ederken (Ateş, Çetinkaya ve Yıldırım, 2012; Smith, Tracy ve Weber, 1998; Wutz ve Wedwick, 2005); öğrencilere bu anlamda çok da fırsat verilmediğine dair araştırma sonuçları da (Değirmenci, 2009) bulunmaktadır. Smith, Tracy ve Weber'e (1998) göre okuma materyallerinin çeşitliliğini artırmak ve öğrencilerin seçimine saygı duymak gibi uygulamalar öğrencilerin bağımsızlık ve özsaygı inşa edebilecekleri olumlu okuma deneyimleri arasındadır. Okuma çemberleri, okuma, analiz yapma ve kitap seçimi tartışmaları ile öğrencilerin kendi kararlarını almalarında yol göstericidir. Böylelikle öğrencilerin bağımsızlaşmasında etkili olmaktadır (Blum, Lipsett ve Yocom, 2002). 
Sonuç itibariyle okuma çemberlerinin farklı açılardan katkılarına dair çok sayıda araştırma bulunmaktadır. Amaçlar oluşturmadan düşünce üretimine ve bunların farklı dil becerileriyle ifadesine, tartışma ve paylaşım yoluyla gerek eleştirel düşünme gibi üst düzey zihinsel becerilerin gelişimine gerekse etkileşimler yoluyla sosyal becerilerin gelişimine kadar geniş bir yelpazede bu katkıları ifade etmek mümkündür. Okuma çemberleri sırasında öğrenciler arasında ortaya çıkan sosyal söylemler ve oluşan etkileşimler, farklı açıları görmelerini ve anlamı sosyal olarak yapılandırmalarını sağlamaktadır. Öğrencilerin okuma çemberleri içerisinde birlikte çalışmaları daha üst düzey akademik başarıya ulaşmalarına, olumlu yönde sosyal tutum, okula ve sınıfa aidiyet duygusu geliştirmelerini sağlamaktadır (Guthrie ve Wigfield, 2000). Çok yönlü katkılarından söz edilen okuma çemberlerine ilişkin araştırmalara ise ülkemizde nadiren rastlanmaktadır (Avcı ve Yüksel, 2011; Avcı, Baysal ve Akıncı, 2013). Umuyoruz ki neden okuma çemberleri sorusuna cevapların arandığı bu bölümle birlikte okuma çemberlerinin öğretmenler tarafından öğrenme ortamlarında nasıl uygulanacağına yönelik bu çalışma içerisinde verilen örnek uygulamanın ve okuma çemberlerini teorik açıdan destekleyen kuramların bu alanda daha fazla çalışma yapılmasına katkı sağlayacağı düşünülmektedir.

\section{Okuma Çemberleri Yöntemi ve İlişkili Olduğu Kuramlar}

Okuma çemberlerinin öneminin daha iyi anlaşılabilmesi için okuma çemberlerini oluşturan dinamiklerin farklı kuramlar bağlamında irdelenmesi ve tartışıması yararlı olacaktır. En iyi okuma yazma uygulamalarını tespit etmek amacı ile yapılan birçok araştırma etkileşimsel (interaktif) yaklaşımı sınıf içi uygulamalarda kullanılması gereken en iyi yollardan biri olarak göstermektedir (Cummins, 2003; Kendall ve Khuon, 2005). Bu kuram, okumayı etkileşime dayalı karşılıklı bir alışveriş (işlemsel-dönüşümsel) süreci olarak tanımlamaktadır. Diğer okuma kuramlarında olduğu gibi anlam ne sadece metinde ne de okuyucunun kendisindendir. Okuduğunu anlama öğretimi ile ilgili etkili tüm uygulamalar kültürel pedagoji bağlantılı süreçleri içermektedir (Yoon, 2007). Bu yaklaşım, öğrencilerin okuma sürecinde tartışmaya dayalı zengin içerikli etkinliklerle meşgul olmasını (Beck ve McKeown, 2006; Kong ve Pearson, 2003), okuduğunu anlama ve kelime hazinesini geliştirmeye yönelik doğrudan strateji öğretimini (Avalos, Plasencia, Chavez ve Rascón, 2007/2008) gerektirmektedir. Küçük gruplarda çalışma, strateji öğretimi ve ihtiyaç duyulan desteği sağlamak için en etkili yol olarak ifade edilmektedir (Valencia ve Buly, 2004).

Okuma çemberlerine dayalı okuma çalışmaları sosyal yapılandırmacııık açısından değerlendirildiğinde; okuma öğretimini öğrenciler, metin, akranlar ve öğretmen arasında gerçekleşen bir alışveriş (işlemsel-dönüşümsel) süreci olarak nitelendirmek mümkündür. Bilgiyi yeniden yapılandırmak ve oluşturmak için fikirler karşılıklı olarak paylaşılır. Bu sisteme dayalı okuma ve yazma etkinlikleri öğretmenin üretkenliğini artırır, öğrenciler arasındaki ilişkileri geliştirir. Bu üretkenlik ve ilişkiler, öğrencilerin ilgilerini çekecek ve katılımlarını artıracak uygun okuma ve yazma öğretimi 
etkinlikleri ile şekillendirilir (Au ve Raphael, 2000). Bu ilgi ve katılım, öğretmenin sınıf ortamına getirdiği etkinlikler ve öğrencilerin bu etkinliklerle yaşamları arasında kurduğu anlamlı ilişkiler doğrultusunda en üst seviyeye çıkar. Öğretmen kurulan bağlantıları bağımsız okumalar, yazma etkinlikleri ve metne dayalı informal konuşmalarla ortaya çıkarır. Öğretmen bu süreçte hem sosyal becerileri hem de gerekli olan okuma ve yazma becerilerini doğrudan vurgular ve öğretim sürecine rehberlik eder. Yine öğretmen öğretim sürecini bireyselleştirerek (kişiye indirgeme) farklı özelliklere ve ihtiyaçlara sahip öğrencilerin sosyal ve kişisel ihtiyaçlarına cevap vermeye çalışır (Au ve Raphael, 2000). Genel olarak yeniden ifade etmek gerekirse okuma çemberleri uygulamaları etkileşimsel ve dönüşümsel okuma modelleri ile sosyal yapılandırmacılık kuramından beslenmektedir (McElvain, 2010). Aşağıda bu model ve kuramın okuma çemberleri bağlamında nasıl bir yapı oluşturduğu görselleştirilerek sunulmuştur.

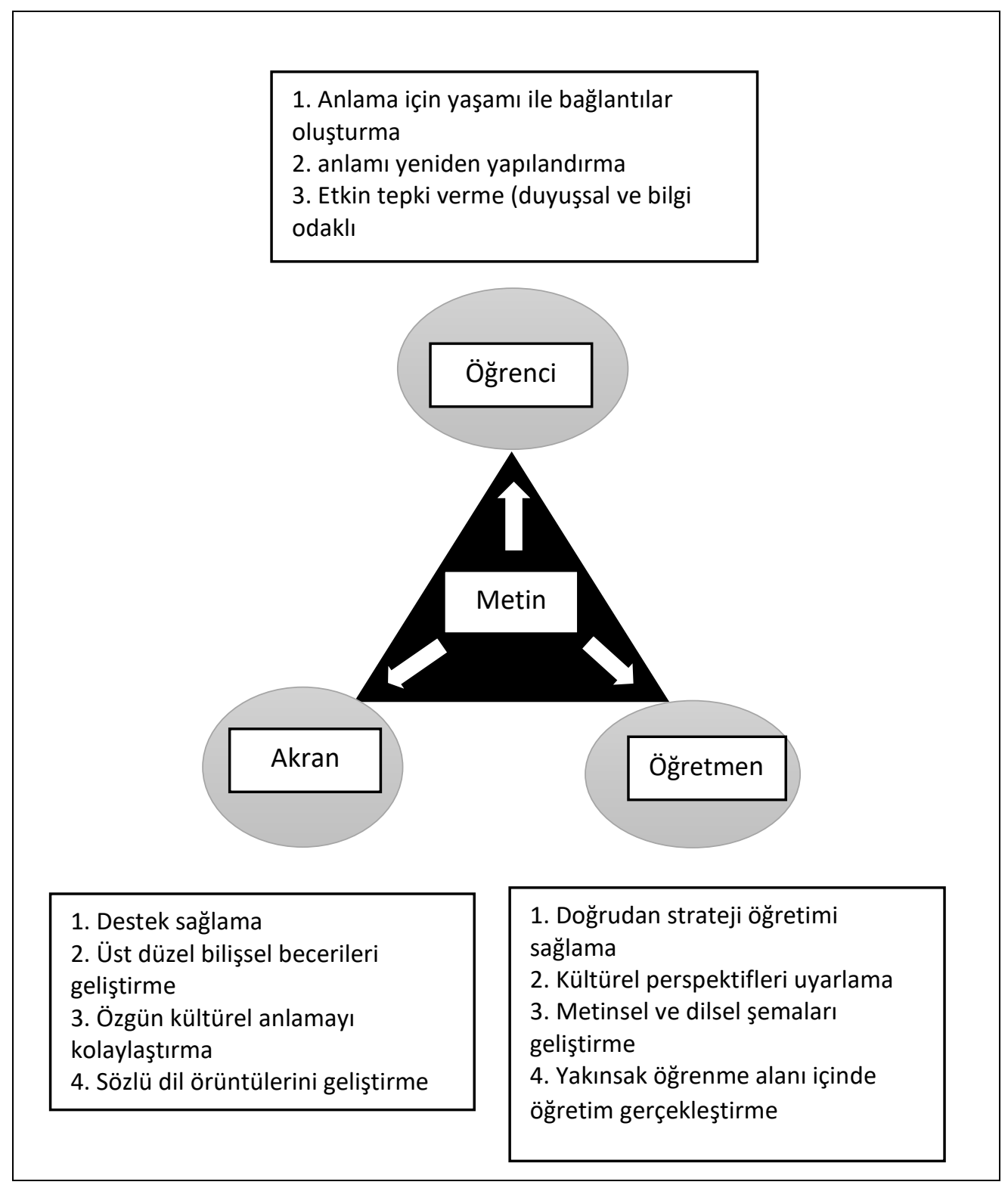

Şekil 1. Etkileşimsel okuma çemberlerindeki etkileşimler (McElvain, 2010, s.183). 
Şekil 1 incelendiğinde, ortak bir metin etrafında bir araya gelen öğrenci, akranlar ve öğretmenin okuma çemberlerinin temel dinamiklerini oluşturduğu görülmektedir. Bleich (1978) her bir okuma deneyiminin, hem diğer okumalarla hem de okuyucunun çevresinde yer alan diğer okuyucularla ilişkili olduğunu ifade etmiştir (akt. Short, 1986). Bu çerçevede okuma çemberleri ile yapılan okuma çalışmalarında öğrenci gelişiminin kendi deneyimleriyle birlikte sürecin diğer paydaşları olan akran ve öğretmenin sürece katkıları doğrultusunda şekilleneceğini söylemek mümkündür. Bu süreçte öğretmenin temel görevi Vygotsky'nin (1978) olası gelişim alanı ('zone of proximal development') kavramı ile ifade ettiği alan içerisinde öğrenciye ihtiyaç duyduğu destek ve rehberliği sağlamaktır. Yapının sosyal doğası gereği öğrencinin ihtiyaç duyduğu bu destek kimi zaman kendisinden belirli konularda daha yetkin olan akranlarından gelebilir ki bu durum okuma çemberlerinin en güçlü yanlarından biridir. Çünkü yapı içerisindeki her öğrenci aynı zamanda diğerleri için belirli konularda birer destek sağlayıcı, beceri geliştirici ve anlamayı kolaylaştırıcı niteliğindedir. Bu kapsamda her bir öğrenciden beklenen temel rol ise sürece etkin katılımdır. Rehber eşliğinde gerçekleşen, kişilerin ortaklığını, iletişimini ve anlamı birlikte yapılandırmalarını gerektiren bu süreç (Hayward, 2002) öğrenciden yaşantısı ile bağlantılar oluşturmasını, anlamı yeniden yapılandırmasını ve duyuşsal ve bilgi odaklı etkin tepkiler vermesini gerektirmektedir.

Teorik olarak okuma çemberlerini destekleyen kuramlar ve eğitim ortamlarındaki pratikleri verildikten sonra Okuma çemberleri ile ilgili örnek bir uygulamaya geçebiliriz. Aşağıda okuma çemberlerini nasıl uygulanacağına yönelik örnek bir uygulama sunulmuştur.

\section{Okuma Çemberleri Nasıl Uygulanır?}

Öğrencilerin okumalarını bilişsel, duyuşsal ve sosyal yönlerden geliştirmelerine katkı sağlayan okuma çemberleri farklı eğitim kademelerinde ve farklı sınıf düzeylerinde kullanılabilecek etkili bir yöntemdir. Öğretmenin amacı ve öğrencilerinin ihtiyaçları doğrultusunda bu uygulama zenginleştirebilir. Sunulan bu örnek uygulamanın öğretmenlere bir bakış açısı sağlayacağı düşünülmektedir.

\section{Okuma Çemberlerinin Adım Adım Uygulanışı}

Okuma çemberlerindeki gruplar nasıl oluşturulmaktadır, oluşturulan gruplarda hangi roller paylaşılmaktadır, rollerle ilgili üstlenilen sorumluluklar nelerdir, tartışma nasıl yürütülür ve son olarak değerlendirme nasıl yapılır? Tüm bu soruların cevaplarının bulunacağı örnekler ve açıklamalar adım adım aşağıda sunulmuştur.

Grupların oluşturulması: Dört ya da beş kişi seçtikleri kitap doğrultusunda bir araya gelerek grupları oluşturur. Gruplar sabit değildir. Her oluşturulan okuma çemberinde öğrenciler farklılaşır. 


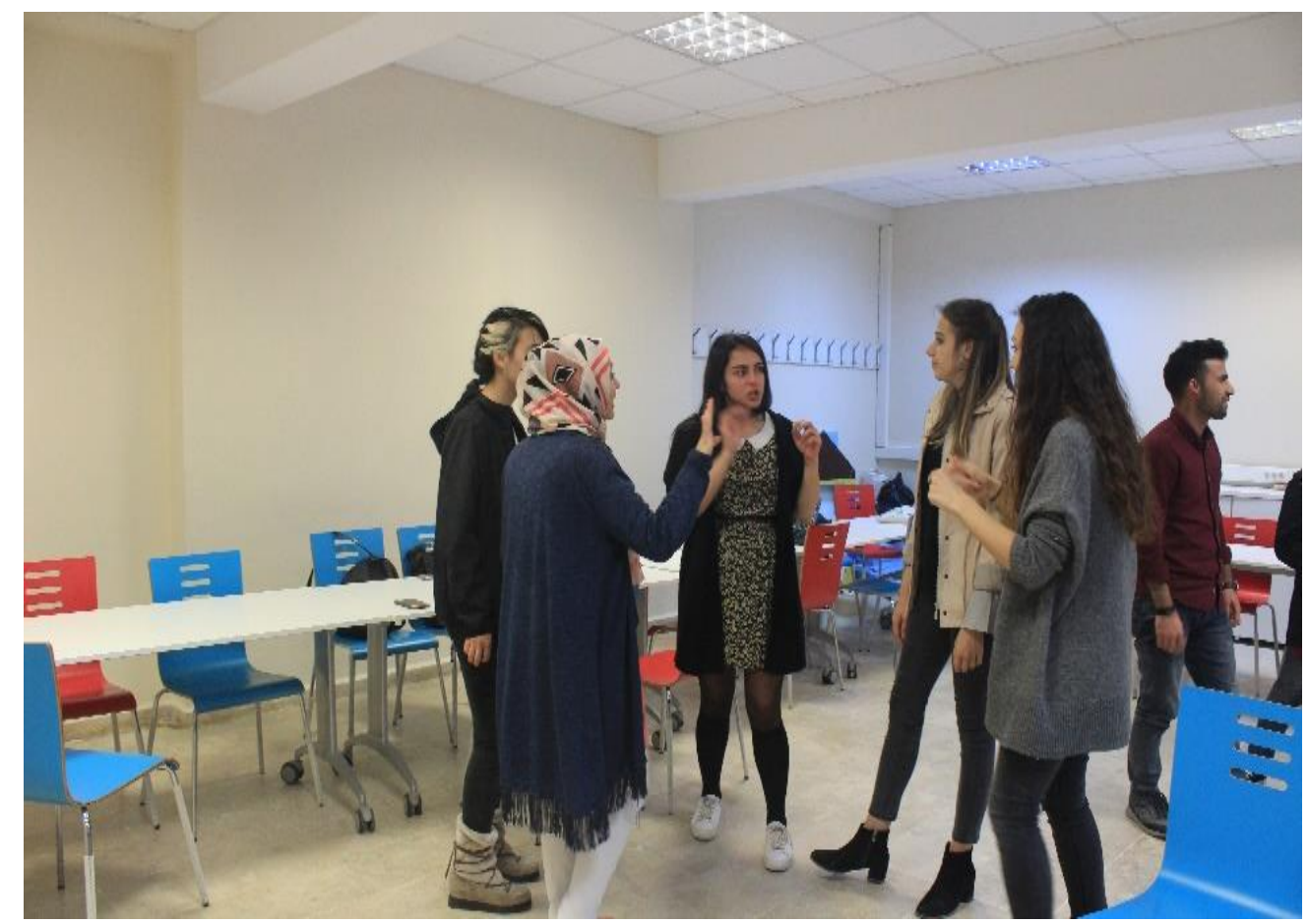

Şekil 2. Fotoğraf, okuma çemberleri gruplarında öğrencilerin nasıl bir araya geldiğini göstermektedir. Bu fotoğraf TÜBITAK 1001 "Bir adım da biz atalım: Okuyalım, paylaşalım, okutalım ve yayalım" projesine katılan öğrencilerden izin alınarak ve proje yürütücüsünün onayıyla bu makaleye eklenmiştir (2018).

Rollerin paylaşılması: Tartışma etkinliklerinde her öğrencinin alması gereken bir rol vardır. Bu roller temel roller ve seçimlik roller olmak üzere iki grupta sınıflandırılmaktadır (Daniels, 2002). Temel roller bağ kurucu, sorgulayıcı, okuma aydınlatıcısı ve ressamdır. Seçimlik roller ise özetleyici, araştırmacı, sözcük avcısı, hareket izcisi ve karakter çözümleyicidir. Öğrenciler bu rollerden birini alırlar. Ancak bir sonraki okuma çemberinde her bir öğrenci önceki aldığı rol dışında bir rolü almak durumundadır.

Rollerin gerektirdiği sorumlulukların yerine getirilmesi: Grup üyelerine, aldıkları rollere ilişkin çalışma yaprakları verilir. Her bir çalışma yaprağında üyelerin rolünün gerektirdiği işler, yönergelerle açıklanmıştır. Grup üyeleri kendilerine verilen görevleri yapmakla yükümlüdür.

Bağ kurucu: Kitapla dış dünya arasında bağ kurmakla yükümlüdür. Bir başka deyişle bu role sahip kişi okudukları ile kendi yaşantısı, okul yaşantısı ya da başka bir topluluktaki yaşantılarıyla, farklı zaman ve yerdeki benzerlikler ya da problemlerle bağlantılar kurmaya çalışır. 


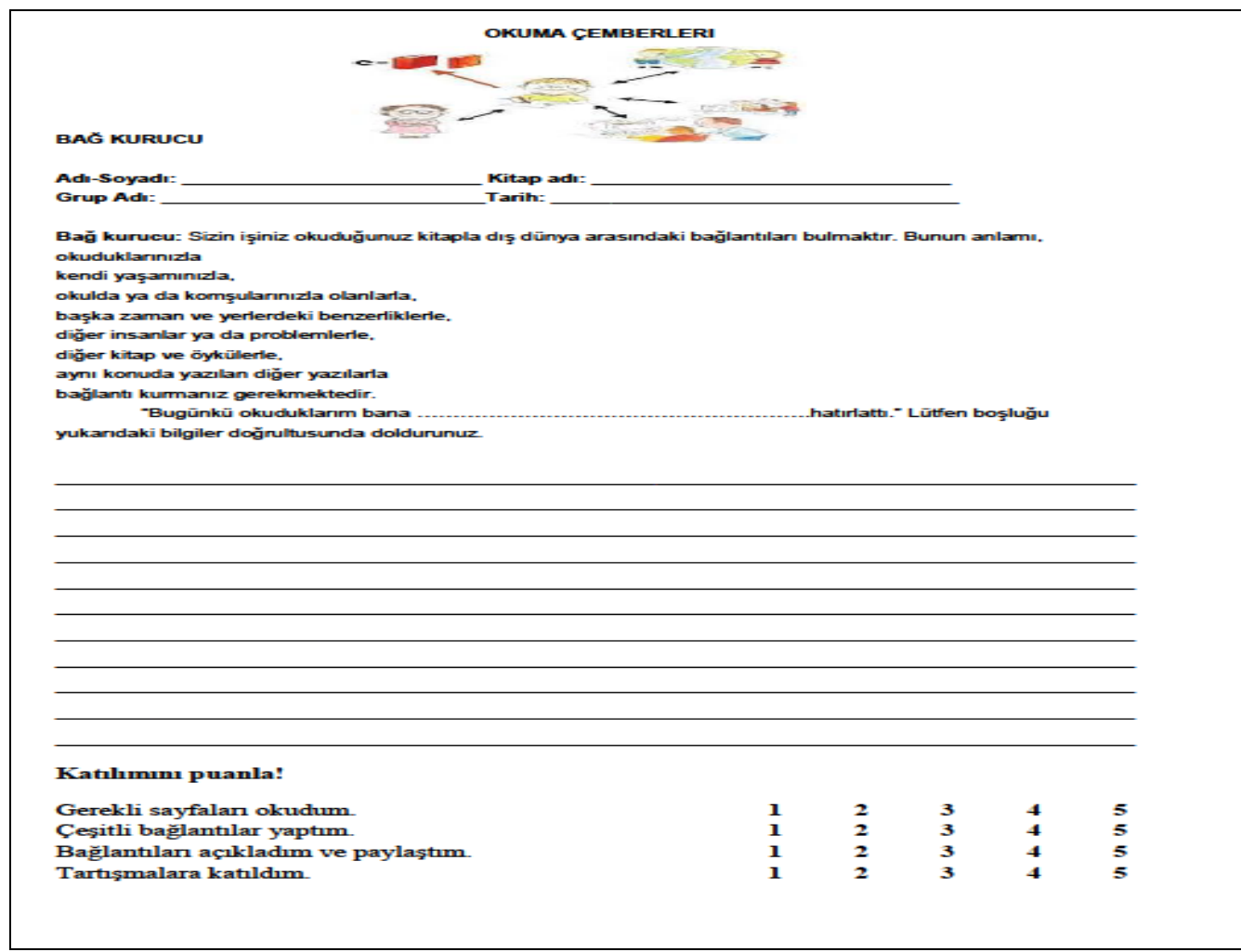

Şekil 3. Çalışma yaprağı (Bağ kurucu), (Daniels, 2002)'den uyarlanarak alınmıştır.

Ressam: Okuduğu bölümle ilgili bir resim çizmekle görevlidir. Bu, kroki, çizgi karakter, diyagram vb. olabilir. Okumanın kendisine hatırlattığı bir şey ya da öykünün bir öğesi (konu, karakter, olay) olabilir.

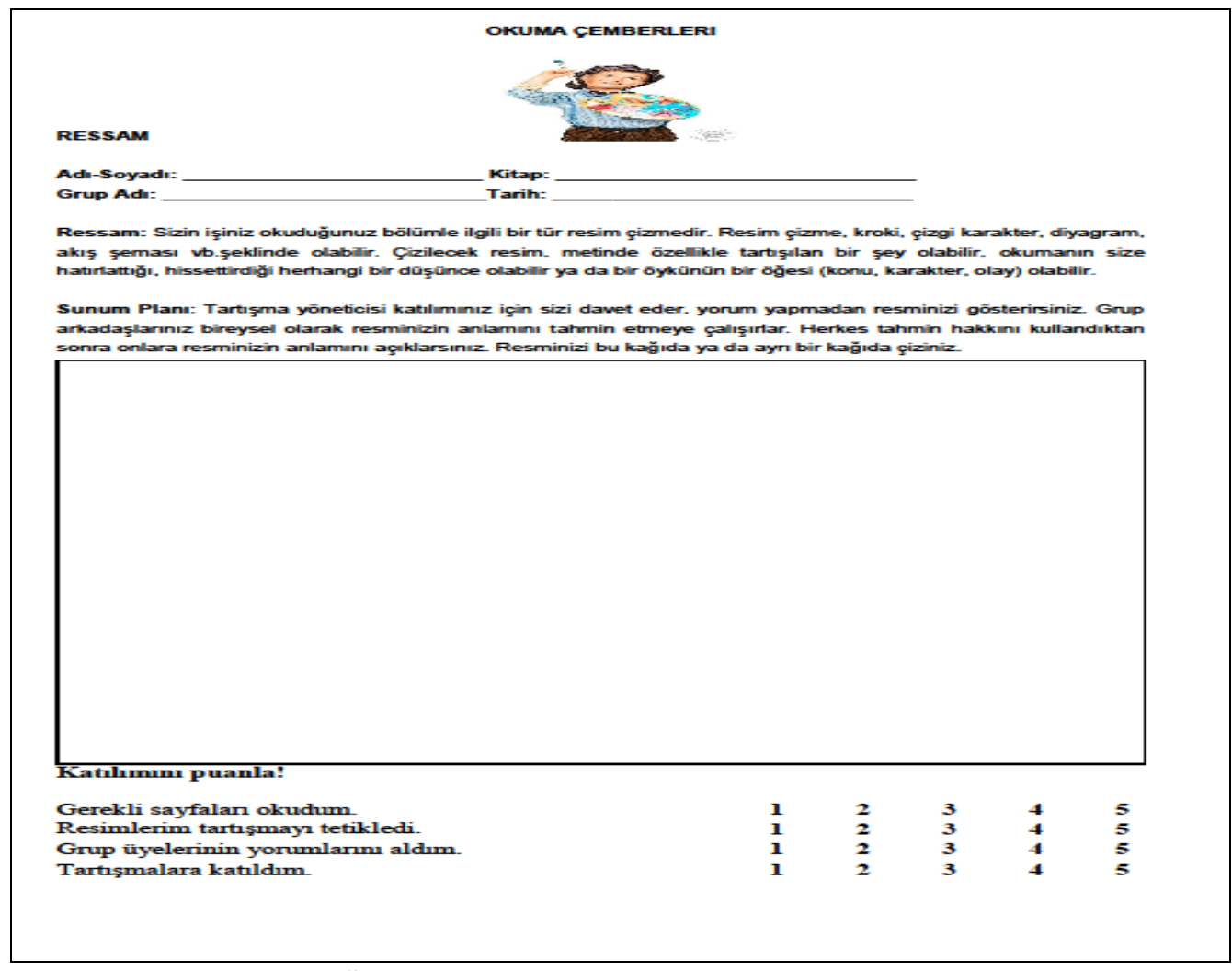

Şekil 4. Çalışma yaprağı (Ressam), Daniels, H. (2002, (Daniels, 2002)'den uyarlanarak alınmıştır. 
Sorgulayııı: Grupta tartışmayı sağlayacak şekilde sorular hazırlamakla yükümlüdür. Bu rolü alan üyeler, "Okurken merak ettikleriniz nelerdir, betimlenen şeylerle ilgili sorularınız var mı, şu sözcük ne anlama geliyor?" şeklinde düşüncelerini ve hissettiklerini ortaya koymaya yönelik sorular hazırlamaya çalışmalıdır.

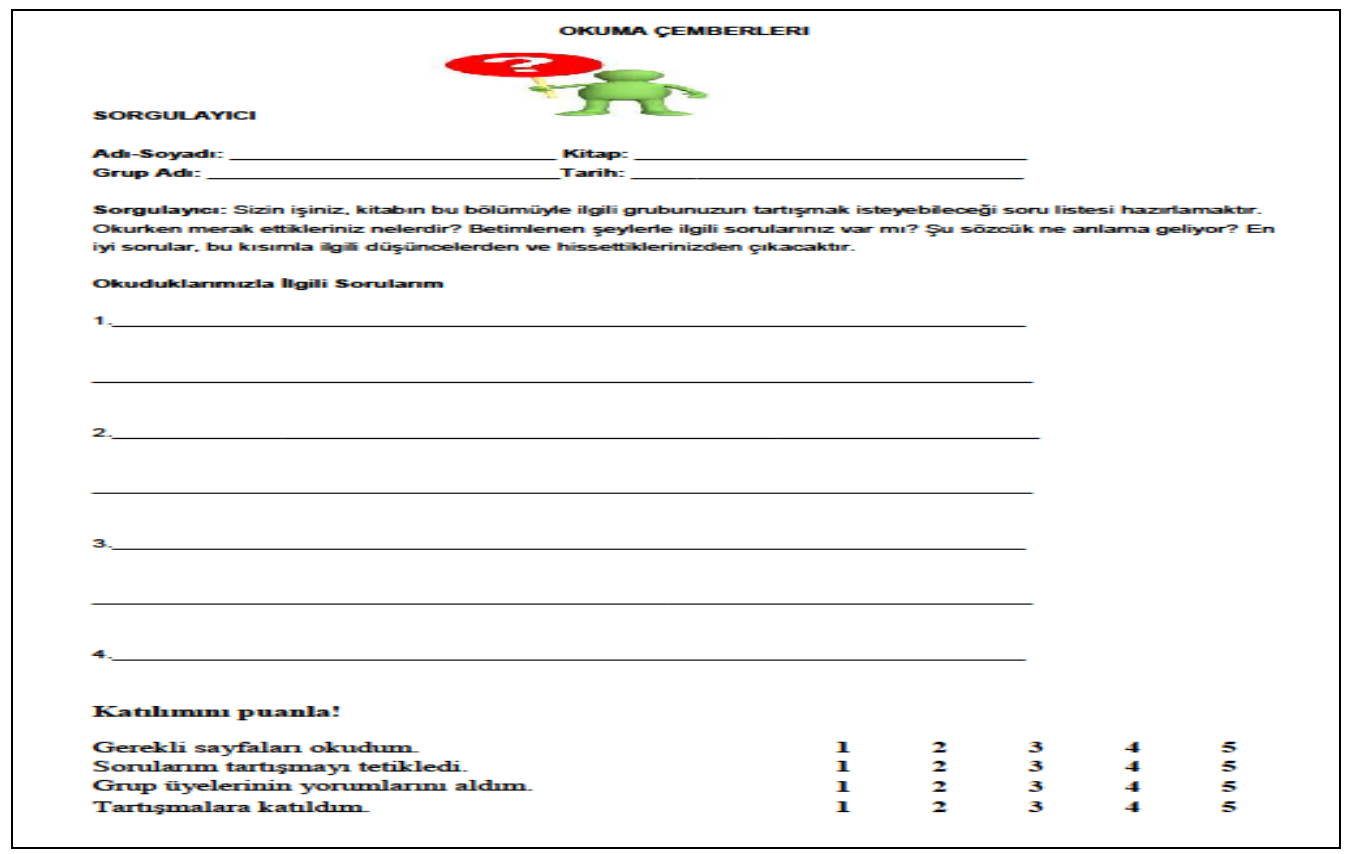

Şekil 5. Çalışma yaprağı (Sorgulayıcı), (Daniels, 2002)'den uyarlanarak alınmıştır.

Okuma aydınlatıcısı: Grubuyla tartışmak amacıyla kitaptan bir paragraf ya da cümle seçmekle görevlidir. Amacı, kitaptaki ilginç, güçlü, eğlenceli, şaşırtıcı, önemli bir şeyi seçip diğer arkadaşları ile paylaşmaktır.

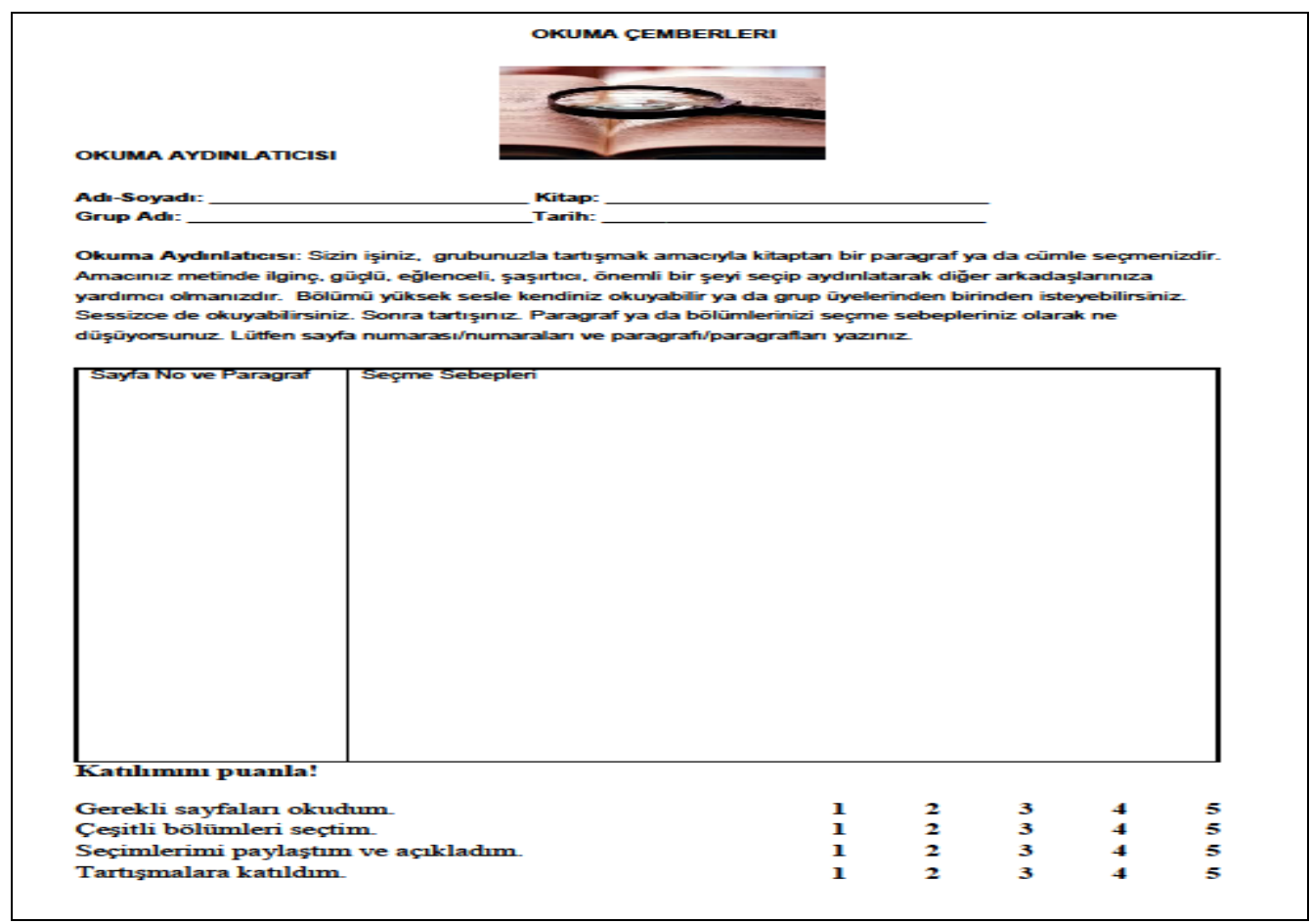

Şekil 6. Çalışma yaprağı (Okuma aydınlatıcısı), (Daniels, 2002)'den uyarlanarak alınmıştır. 
Grupta temel roller alındıktan sonra seçimlik rollerden tercihe dayalı olarak roller seçilir. Bu kapsamda seçimlik roller ile bu rollerin gerektirdiği sorumluluklara değinilmiştir. Seçimlik rollere dayalı örnekler aşağıda sunulmuştur.

Özetleyici: Okuduklarının özetini çıkarmakla yükümlüdür. Öyküyü yeniden anlatır gibi özetlemelidir. Öykünün tümünü değil, sadece önemli bölümlerine odaklanarak anlatır. Sözcükler ve cümleler kendi cümleleri olmalıdır.

Sözcük avcısı: Okuduklarında önemli ve anlamını bilmedikleri sözcükleri ya da kavramları araştırmakla görevlidir. Okurken bilinmeyen sözcükleri bulup hemen işaretler ve sözlükten anlamını araştırıp yazar.

Tahmin edici: Okuduklarının ışığında sonradan olabileceklere ilişkin tahminlerde bulunmakla görevlidir. Bir karakterin ne yapacağına, bir sonraki olayın ne ya da nerede olacağına ilişkin tahminlerde bulunur.

Hareket izcisi: Karakterlerin çok hareket ettiği ya da sahnelerin sık sık değiştiği bir kitapta olayların olduğu yeri ve olayların geçtiği yerin nasıl değiştiğini bilmelidir. Sahne çok fazla değişmemişse olayın geçtiği yer, hâlâ öykünün çok önemli bir bölümüdür. Hareket izcisinin işi, eylemin gerçekleştiği yerin izini sürmektir. Gruptaki arkadaşlarına göstermek ve aynı zamanda tartışmak için öykünün geçtiği yeri, ayrıntılı olarak sözcüklerle ya da haritayla tanımlar.

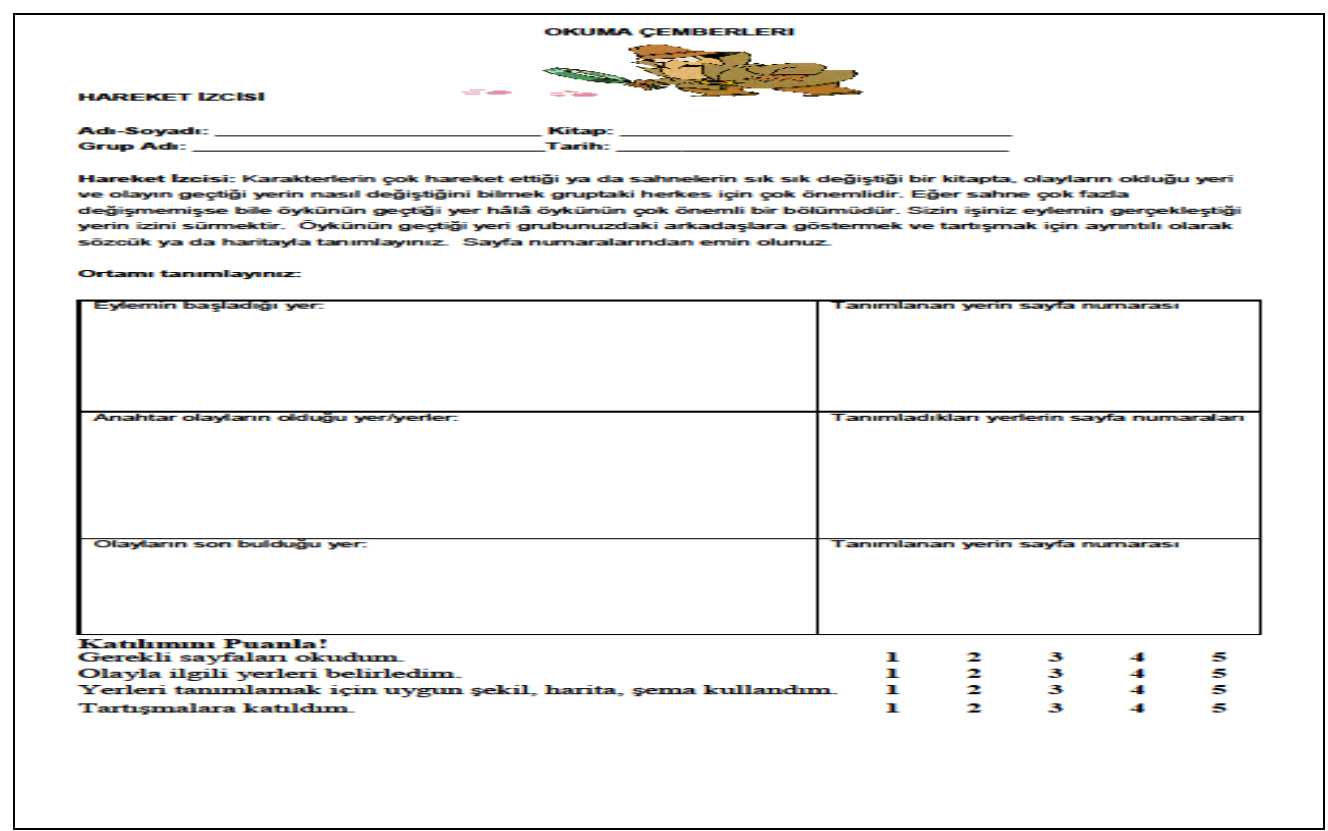

Şekil 7. Çalışma yaprağı (Hareket izcisi), (Daniels, 2002)'den uyarlanarak alınmıştır.

Karakter çözümleyici: Okuduğu kitaptaki karakterlerin özelliklerini yazmakla yükümlüdür. Karakterlerin nelerden hoşlandığına, neleri bildiklerine dair bilgi verirler. Çevrelerindeki kişilerin özellikleri ile de karşılaştırmalar yaparlar. 
Tartışmanın yapılması: Alınan roller doğrultusunda tartışma yürütülür. Bağ kurucular, önceki deneyimlerini, çevreleri, okul ya da başka bir toplulukta olanlarla ilişkilendirdikleri yaşantılarını, farklı zaman ve yerle kurdukları ilişkileri, farklı kişilerle ya da problemlerle kurdukları bağlantıları sunarlar. Sorgulayıcılar, sorularını yöneltir. Sorulara hep birlikte cevap aranır.

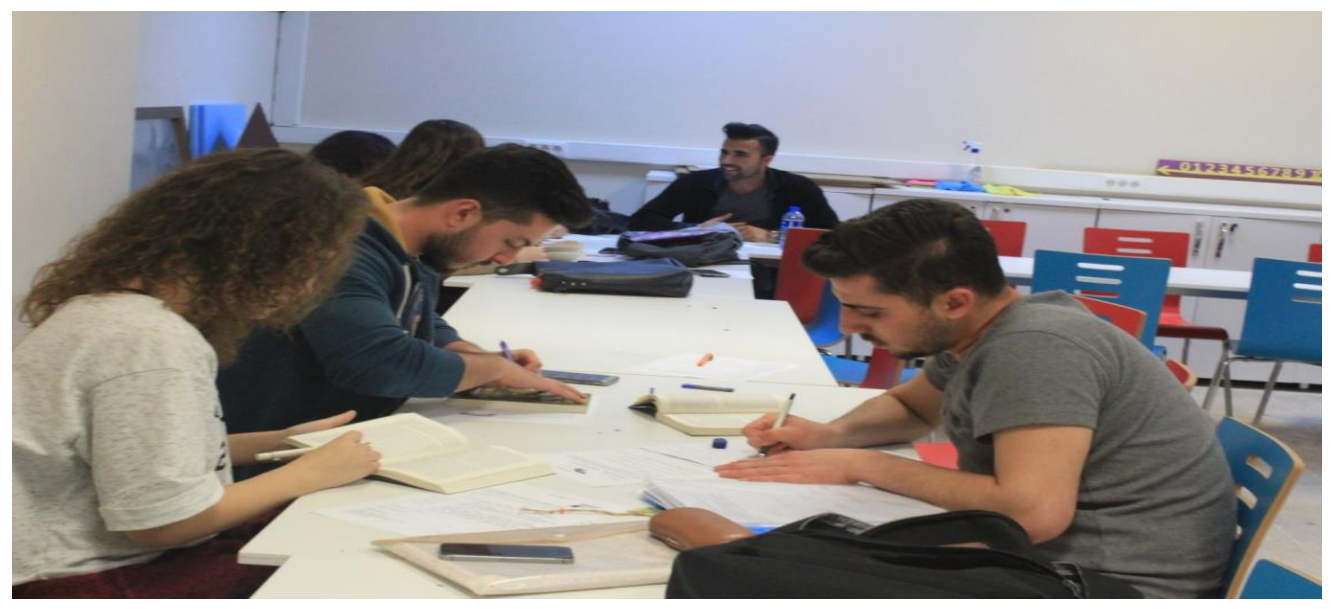

Şekil 8. Fotoğraf, okuma çemberleri gruplarında öğrencilerin üstlendikleri roller doğrultusunda çalıştıklarını göstermektedir. Bu fotoğraf TÜBiTAK 1001 "Bir adım da biz atalım: Okuyalım, paylaşalım, okutalım ve yayalım" projesine katılan öğrencilerden izin alınarak ve proje yürütücüsünün onayıyla bu makaleye eklenmiştir (2018).

Okuma aydınlatıcıları, kitaptaki seçtikleri ilginç, güçıü, eğlenceli, şaşırtıcı, önemli şeyleri içeren paragraf ya da cümleleri sunarlar ve tartışılar. Ressamlar, okudukları bölüme ilişkin öykünün bir öğesine (konu, karakter, olay) dair çizdikleri resimleri -ki bunlar kroki, çizgi karakter, diyagram vb. olabilir- sınıfa sunarlar. Alınan bu temel roller dışında seçimlik rolleri alanlar ise rollerinin gerektirdiklerini yapıp sınıfa sunarlar ve paylaşırlar.

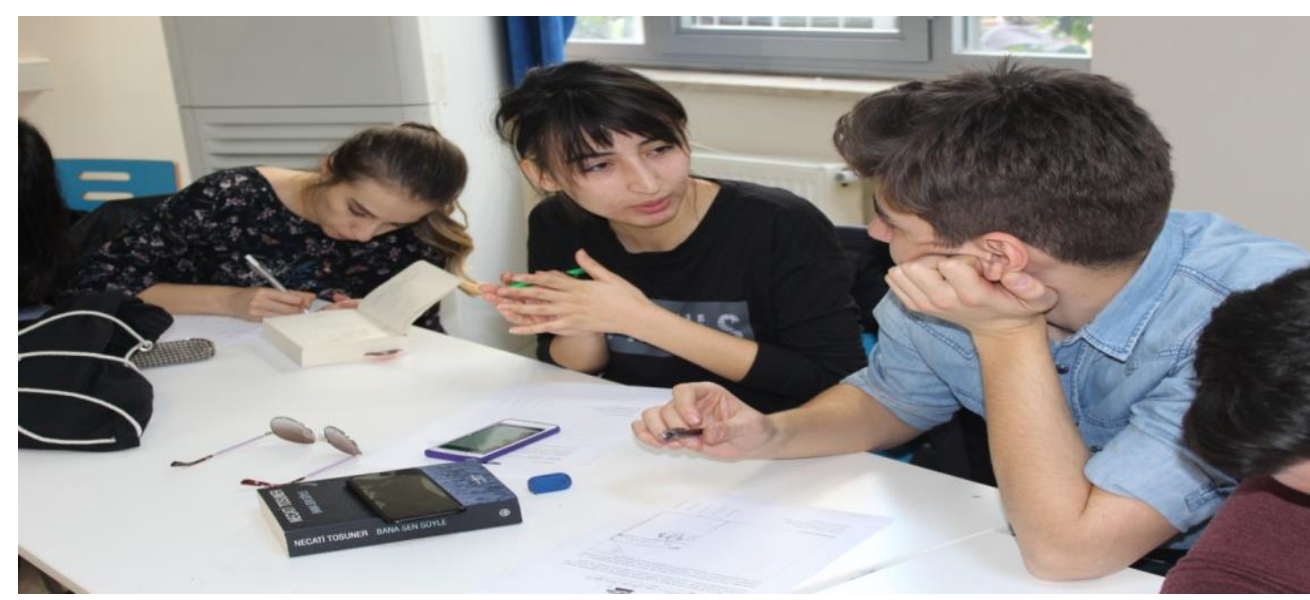

Şekil 9. Fotoğraf, okuma çemberleri gruplarında öğrencilerin üstlendikleri roller doğrultusunda tartışma yaptıklarını göstermektedir. Bu fotoğraf TÜBiTAK 1001 "Bir adım da biz atalım: Okuyalım, paylaşalım, okutalım ve yayalım" projesine katılan öğrencilerden izin alınarak ve proje yürütücüsünün onayılla bu makaleye eklenmiştir (2018). 
Değerlendirmenin yapılması: Öğrenciler tarafından seçilen kitapların iki haftalık zaman diliminde bitirilmesine özen gösterilir. Değerlendirme yapılırken hem süreç hem de sonuç değerlendirmeleri çağdaş yaklaşımlara uygun bir biçimde gerçekleştirilir. Öğrencilerin üstbilişsel becerilerini geliştirmek amaçlı öz değerlendirmeler yapılır. Bu bağlamda her bir öğrenci kendi güçlü yönlerini fark ederken aynı zamanda eksikliklerini, zayıf ve geliştirmesi gereken yönlerini de görmüş olur. Bu amaçla yapılabilecek öz değerlendirmeye uygun olarak aşağıdaki form kullanılabilir.

\section{ÖĞRENCI ÖZ DEĞERLENDIRME FORMU}

Cember No: Kitap adı:

\begin{tabular}{|c|c|c|c|c|}
\hline & Evet & Kusmen & Hayr & Yorumlar \\
\hline \multicolumn{5}{|l|}{$\begin{array}{l}\text { Okuma çemberine hazırlıklı } \\
\text { geldim. }\end{array}$} \\
\hline \multicolumn{5}{|l|}{ Grup içindeki rolūmü anladım. } \\
\hline \multicolumn{5}{|l|}{$\begin{array}{l}\text { Konuşmalan sessiz ve } \\
\text { dikkatlice dinledim. }\end{array}$} \\
\hline \multicolumn{5}{|l|}{ İtiyacı olanlara yardım ettim. } \\
\hline \multicolumn{5}{|l|}{$\begin{array}{l}\text { Grubun bir parçası olmak } \\
\text { hoşuma gitti. }\end{array}$} \\
\hline \multicolumn{5}{|l|}{$\begin{array}{l}\text { Kendimi etkili olarak ifade } \\
\text { ettim. }\end{array}$} \\
\hline \multicolumn{5}{|l|}{$\begin{array}{l}\text { Verilen role uygun } \\
\text { calışmalanm titizlikle } \\
\text { yürüttüm. }\end{array}$} \\
\hline \multicolumn{5}{|l|}{$\begin{array}{l}\text { Grup üyeleri ile işbirliği içinde } \\
\text { çalıştım. }\end{array}$} \\
\hline \multicolumn{5}{|l|}{$\begin{array}{l}\text { Rolümü istekli olarak yerine } \\
\text { getirdim. }\end{array}$} \\
\hline \multicolumn{5}{|l|}{ Farklı fikirlere sayg duydum. } \\
\hline \multicolumn{5}{|l|}{ Bakış açım zenginleşti. } \\
\hline \multicolumn{5}{|l|}{ Kelime dağarcığm zenginlești. } \\
\hline \multicolumn{5}{|l|}{$\begin{array}{l}\text { Kitap sayesinde bilgi } \\
\text { dağarcığmm zenginleşti. }\end{array}$} \\
\hline \multicolumn{5}{|l|}{$\begin{array}{l}\text { Bu kitabin sonunda okumam } \\
\text { gereken yeni şeyler keşfettim. }\end{array}$} \\
\hline $\begin{array}{l}\text { Bu kitabı okumaktan keyif } \\
\text { aldım. }\end{array}$ & & & & \\
\hline
\end{tabular}

Grup içindeki rolünle ilgili beğendiğin 3 şeyi yaz?

Bir dahaki sefere neyi daha farkl yapmak istersin? 
Öte yandan öğrencilerin ve grupların okuma çemberinde göstermiş oldukları performanslar öğretmen tarafından da değerlendirilir. Grup üyelerinin aldıkları rollere ilişkin görevleri yerine getirip getirmedikleri aşağıda sunulan formla değerlendirilebilir.

\begin{tabular}{|c|c|c|c|c|c|}
\hline \multicolumn{6}{|l|}{$\begin{array}{l}\text { Rolleri değerlendirme } \\
\text { Çember No: } \quad \text { Grup Adr: }\end{array}$} \\
\hline Roller & Adh Soyadh & 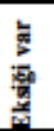 & 产 & 謇 & 를 \\
\hline $\begin{array}{l}\text { Sorgulayıa } \\
\text {-Tartş̧maya rehberlik yapar. } \\
\text {-Tartş̧mayı devam ettirir. } \\
\text {-Düşüunuürücü sorulan sorar. }\end{array}$ & & & & & \\
\hline $\begin{array}{l}\text { Bağ kurucu } \\
\text { - Gerçek yaşam, önceki okuduklan, } \\
\text { kendisi ya da arkadaşlan ile bağ } \\
\text { kurar. }\end{array}$ & & & & & \\
\hline $\begin{array}{l}\text { Olkuma Aydmlathcısı } \\
\text {-ílginç, şaşrtacı, eğlenceli ve } \\
\text { önemli yerleri ortaya çkarr. }\end{array}$ & & & & & \\
\hline $\begin{array}{l}\text { Ressam } \\
\text {-Düşüunceyi ortaya çkanr ve } \\
\text { yaratıcliğ kullanir. }\end{array}$ & & & & & \\
\hline $\begin{array}{l}\text { Hareket izcisi } \\
\text {-Eylemin başladuğ yeri bulur. } \\
\text {-Anahtar olaylanm olduğu yerleri } \\
\text { bulur. } \\
\text {-Olaym son bulduğu yeri bulur. }\end{array}$ & & & & & \\
\hline $\begin{array}{l}\text { Karakter çözümleyici } \\
\text { Karakterleri belirler. } \\
\text { Karakterlerin özelliklerini yazar. }\end{array}$ & & & & & \\
\hline $\begin{array}{l}\text { Sözcük avcası } \\
\text {-Sözcüklerin sôzcük yapı türümū } \\
\text { seçer. } \\
\text {-Anlamlannı yonumlayabilir. } \\
\text {-Sözculk dağarcığmn geniģletebilir. }\end{array}$ & & & & & \\
\hline $\begin{array}{l}\text { Ōzetleyici } \\
\text {-Doğru ve net bilgiyi sağlar. } \\
\text {-Kendi sözcuiklerini kullanarak } \\
\text { anahtar noktalara odaklanir. }\end{array}$ & & & & & \\
\hline
\end{tabular}

Şekil 11. Rolleri değerlendirme formu, (Daniels, 2002)'den uyarlanarak alınmıştır. 
Son olarak okunan kitaba ilişkin grup üyeleri tarafından bir proje sunulur. Bu projeler, drama, afiş hazırlama, kitap kapağı tasarlama, kısa film çekme şeklinde olabilir. Ayrıca okunan kitabın yazarı ile buluşup kitabın değerlendirmesi yapılabilir. İnternet ortamında okunanlar forum şeklinde paylaşılabilir. Öğrencilerin okuduğunu anlama becerilerinin gelişip gelişmediğini görmek için çoktan seçmeli ve açık uçlu sorularla oluşturulan sonuca yönelik ölçme araçları ile değerlendirme zenginleştirilebilir.

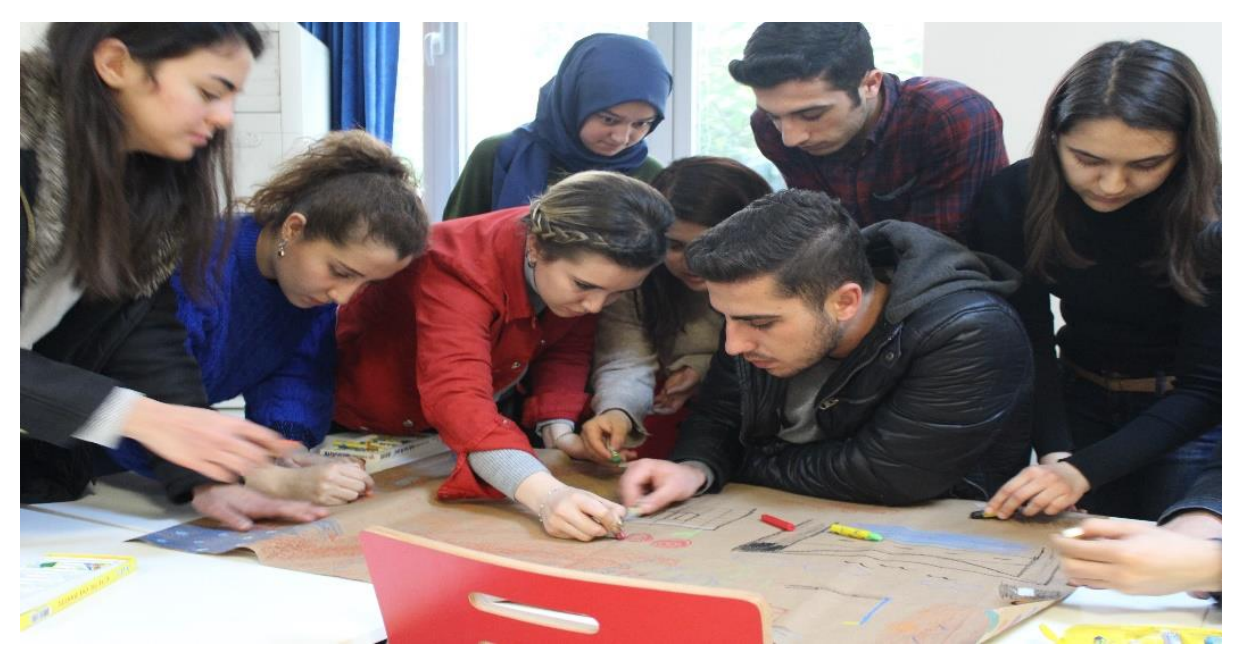

Şekil 12. Fotoğraf, okuma çemberleri gruplarında öğrencilerin ortaya koydukları ürünü göstermektedir. Bu fotoğraf TÜBітAK 1001 "Bir adım da biz atalım: Okuyalım, paylaşalım, okutalım ve yayalım" projesine katılan öğrencilerden izin alınarak ve proje yürütücüsünün onayıla bu makaleye eklenmiştir (2018).

Okunan bir kitaba yönelik oluşturulan çember böylece sonlandırılırken, bir başka kitap seçilip yeni bir çember oluşturulur. Oluşturulan bu çemberde, önceki çemberde yer alan üyelerin farklı öğrencilerle bir araya gelmesine ve üyeler tarafından alınan rollerin de farklılık göstermesine dikkat edilir.

\section{Tartışma, Sonuç ve Öneriler}

Okuma çemberleri, daha önce de ifade edildiği gibi öğretmenin öğrencilerinin bilişsel, duyuşsal ve sosyal yönden okumalarını geliştirmek amacıyla kendine yönelttiği sorulara cevap aramada son derecede etkili yöntemlerden biri olarak karşımıza çıkmaktadır. Aynı öykü, şiir, makale ya da kitapları okumayı seçen öğrencilerin bir araya gelerek oluşturdukları küçük gruplarda farklı rolleri üstlenen öğrenciler, bilişsel, duyuşsal ve sosyal yönden okumalarını geliştiren bir öğrenme ortamı içerisinde bulunmaktadırlar. Oluşturulan her okuma çemberinde alınan roller farklılaşacağından her öğrenci farklı rollerin getirdiği katkılardan yararlanmış olmaktadır.

Okuma çemberlerinde, bilişsel açıdan okuduğunu anlama ve düşünme becerilerini geliştirmeye dayalı etkinlikler yürütülmektedir (Mizerka, 1999; Whittingham, 2013). Örneğin, "sorgulayıcı" rolünü alan bir öğrenci okuduğu kısma ilişkin sorular çıkarmaktadır. Soru sorma 


\section{Okuma Çemberleri: Niçin ve Nasıl? Örnek Bir Uygulama}

stratejisi, alan yazında karşımıza çıkan etkili okuduğunu anlama stratejilerinden bir tanesidir. Bu amaçla örneğin, Soru-Cevap illişkisi (Question Answer Relation-QAR) stratejisi kullanılabilir. Bu strateji, okuduğunuz kitapta cevabı bir cümle içinde olan, cevabı iki ya da daha fazla cümle içinde olan ve cevabı okuduklarında doğrudan olmayıp dolaylı olarak bulunan farklı soru türleri hazırlamayı içerir. Bu yönüyle Soru-Cevap iliş̧kisi stratejisi (QAR), zihinsel olarak farklı düzeylerde oluşturulan soru tiplerini içermektedir (Raphael ve Au, 2005; Doğan, 2006). Bloom'un aşamalı sınıflandırmasına dayalı olarak bilişsel alanın farklı düzeylerine yönelik sorular çıkarılabilir. Bu şekilde farklı düzeylerde ve özellikle üst düzey zihinsel süreçlere yönelik soru hazırlamaya çalışmak öğrencilerin zihinsel yönden gelişimine önemli ölçüde katkı sunmaktadır. Yine "ressam" rolünü alan bir öğrenci, okuduklarını anlamlandırmada etkili bir başka strateji olan resim çizmeyi (Rich ve Blake, 1994) kullanmaktadır. "Hareket izcisi" rolünü alan bir öğrenci ise okuduklarında olayların geçtiği yerleri izlemekte ve bu da onun okuduğunu anlamlandırmasına yardım etmektedir. Sözcük avcısı ya da araştırmacı rollerini alanlar da bilmedikleri sözcük ya da kavramları araştırarak okuduklarını daha iyi anlamlandırmaktadırlar. Böylelikle okuduğunu anlama ve kelime hazinesini geliştirmeye yönelik doğrudan strateji öğretimi yapılmaktadır (Avalos ve diğ., 2008). Öte yandan "özetleyici", okuduklarında önemli bölümleri, anahtar sözcükleri ya da olayları belirterek, "tahmin edici" de okuduklarından sonra olacakları düşünecekleri için okuduklarını daha iyi yapılandırmaktadırlar. "Bağ kurucu" rolünü alan bir öğrenci, okuduklarını önceki bilgileriyle, okulda ya da çevresindeki yaşantılarla ilişkilendirmekte, başka kitaplarla bağlantılarını kurmakta, farklı zaman dilimleri ve farklı yerlerle benzerliklerini irdelemektedir. Böylelikle yeni bilgi ile ilgili ön bilgilerin bir araya getirilerek işlendiği süreç olarak tanımlanan öğrenme sürecinin (Lyons ve Pinnell, 2001) gerçekleşmesine katkıda bulunulmaktadır. Bu, aynı zamanda yapılandırmacı yaklaşıma uygun olarak zihinde anlamlandırmanın gerçekleştirilmesini sağlamaktadır. Benzer şekilde "karakter çözümleyici" rolünü alan bir öğrenci de karakterlerle kendi çevresindeki kişilerin benzerliklerini irdeleyerek ilişki kurmakta ve zihninde anlamı yapılandırmaktadır. Anlama süreci etkilenme ve tepki verme eylemidir (Pearson ve diğ, 2008). Öğrenciler okuma çemberlerinde sürekli düşündükleri ve etkileşimde bulundukları için okuduklarını yüzeysel değil daha derin anlamlandırmaktadırlar. Öte yandan okuyucu okuma çemberleri uygulamalarında daha belirgin amaçlar oluşturabildiği için bu, daha iyi anlamalarına yardımcı olacaktır (Zimmerman, 2007, akt. Pambianchi, 2017).

Okuma çemberlerinde duyuşsal yönden yine birçok etkinlik yapılmaktadır. Öncelikle öğrenci okuyacağı kitabı kendisi seçmekte, yani karar vermektedir (Tomlinson ve Strickland, 2005). Bu anlamda öğrenmenin sorumluluğunu almaktadır. Kitabı kendisi seçtiği için okumaktan zevk almaya başlamakta ve okumaya yönelik olumlu tutum geliştirmektedir. Okuduklarını tartışma yoluyla grup içinde paylaşmakla, kendini ifade etmekle öz güven duygusu gelişmektedir. Okuma çemberleri, kitap 
seçimi tartışmaları ile öğrencilerin kendi kararlarını almalarına yardımcı olmaktadır (Blum ve diğ., 2002). Böylelikle öğrenciler, giderek daha bağımsız öğrenenler haline gelmektedirler. "Okuma aydınlatıcısı" rolünü alan öğrenci okuduklarında kendine en ilginç gelen, onu şaşırtan, eğlenceli kısımları seçip arkadaşları ile paylaşmaktadır. Bu yolla öğrencilerde okuma ilgisi ve olumlu tutum oluşmaya başlamaktadır. "Bağ kurucu" rolünü alan öğrenci ise yeri geldiğinde kendisini karakterlerin yerine koymakta ve bu yolla empati becerileri gelişebilmektedir.

Sosyal yönden okuma çemberlerinde öğrenciler aldıkları roller gereği tartışmaya katılmakta ve bilgilerini birbirleriyle paylaşmaktadırlar. Bu yolla birbirlerini dinlemekte, birbirlerinin görüşlerine saygı duymakta ve iş birliği içinde hareket etmektedirler. Her okuma çemberinin sonunda grup olarak ortaya bir ürün koyacakları için, birbirlerine yardım etmekte, destek olmaktadırlar. Bu yönleri nedeni ile öğrenciler, etkileşim içinde olmakta ve böylece iletişim becerileri gelişmektedir. Öte yandan, Guthrie ve Wigfield'ın (2000) da belirttiği gibi okuma çemberleri sırasında öğrenciler arasında oluşan etkileşimler, farklı bakış açılarını görmelerini ve anlamı yapılandırmalarını sağlamaktadır. Öğrencilerin okuma çemberleri içerisinde birlikte çalışmaları daha üst düzey akademik başarıya ulaşmalarına, olumlu yönde tutumlar geliştirmelerine, birlikte çalışma alışkanlığı kazanmalarına, okula ve sınıfa aidiyet duygusu geliştirmelerine katkı sağlamaktadır.

Genel olarak okuma çemberleri yöntemi, yapılandırmacı anlayış çerçevesinde sınıflarında öğrenci merkezli yöntemleri kullanmak isteyen öğretmenler tarafından somut bir örnek uygulama olarak kullanılmayı beklemektedir, denilebilir. Bu yöntem dinleme, konuşma, yazma ve okuma gibi dil becerilerini geliştirmeye yönelik kullanılabilecek olmasının yanında öğretmenlere farklı disiplinlerde öğrencilerin bilişsel, sosyal ve duyuşsal yönden gelişimlerinde yardımcı olacak olanaklar sunacaktır.

\section{Kaynaklar}

Avalos, M.A., Plasencia, A., Chavez, C. ve Rasco' n, J. (2007/2008). Modified guided reading: Gateway to English as a second language and literacy learning. The Reading Teacher, 61(4), 318-329.

Avcl, S. ve Yüksel, A. (2011). Cognitive and affective contributions of the literature circles method on the acquisition of reading habits and comprehension skills in primary level students. Kuram ve Uygulamada Eğitim Bilimleri, 11, 3, 1295-1300.

Avcı, S., Baysal, N., Gül, M. ve Akıncı, Y. (2013) Okuma çemberi yönteminin okuduğunu anlama becerisine etkisi, Kuramsal Eğitimbilim Dergisi, 6(4), 535-55.

Au, K. ve Raphael, T. (2000). Equity and literacy in the next millennium. Reading Research Quarterly, 35(1), 170-172.

Ateş, S., Çetinkaya, F. ve Yıldırım, K. (2012). Okunabilir bir kitap nasıl seçilir? ilköğretim Online, 11 (2), 319-331.

Beck, I. ve McKeown, M. (2006). Improving comprehension with questioning the author: A fresh and expanded view of a powerful approach. New York: Scholastic.

Blum, H.T., Lipsett, L.R. ve Yocom, D.J. (2002). Literature Circles: A Tool for Self-Determination in One Middle School Inclusive Classroom. Remedial and Special Education, 23, 2, 99-108. 
Brabham, E.G. ve Villaume, S.K. (2000). Continuing conversations about literature circles. The Reading Teacher, 54 (3), 278-80.

Campbell Hill, B. (2010). Literature Circles and the Heart of Response (Grades 1-8), CEESA Conference Tallinn, Estonia.

Cummins, J. (2003). Reading and the bilingual student: Fact and friction. In G.G. Garcia (Ed.), English learners reaching the highest level of English literacy. (pp. 2-33). Newark, DE: International Reading Association.

Daniels, H. (1994). Literature circles: Voice and choice in student-centered classroom. Portland, ME: Stenhouse.

Daniels, H. (2002). Literature circles: Voice and choice in book clubs and reading groups. Portland, ME: Stenhouse.

Değirmenci, H. (2009). İlköğretim okullarında düzenlenen okuma saatlerinin değerlendirilmesine ilişkin öğretmen görüşleri. Yayımlanmamış yüksek lisans tezi, Gazi Üniversitesi, Ankara.

Doğan, B. (2006). "Strateji öğretiminin, işbirlikli ve geleneksel sınıflarda okuduğunu anlama becerileri üzerindeki etkileri", Eğitim Araştırmaları Dergisi, 6(23), 82-93.

Guthrie, J. T. ve Wigfield, A. (2000). Engagement and motivation in reading. In M. L. Kamil, P. B. Mosenthal, P. D. Pearson ve R. Barr (Eds.), Handbook of reading research: Volume III (pp. 403-419). New York, NY: Routledge.

Hayward, S.M. (2002). A descriptive study of literacy learning and teaching during an author study/visi. Unpublished doctoral dissertation, The Ohio State University, Ohio.

Kendall, J. ve Khuon, O. (2005). Making sense: Small-group comprehension lesson for English language learners. Portland, ME: Stenhouse Publishers.

Kong, A. ve Pearson, D. (2003). The road to participation: The construction of a literacy practice in a learning community of linguistically diverse learners. Research in the Teaching of English, 38(1), 85-124.

Lyons, C. ve Pinnell, G. S. (2001). Systems for change in literacy education: A guide to professional development. Portsmouth, NH: Heinemann.

Marshall, J.C. (2006). The effects of participation in literature circles on reading comprehension. (Unpublished Doctoral dissertation). University of Miami, Coral Gables, Florida.

Mizerka, P.M., (1999). The impact of teacher directed literature circles versus student-directed literature circles on reading comprehension at the sixth-grade level. (Unpublished Doctoral dissertation). Illinois University

McElvain, C. (2009). English learners reading in the transactional learning community. In J.L. McConnell-Farmer (Ed.), The education of young children: Research and public policy. (pp. 47-64). Louisville, KY: Linton Atlantic Books Ltd.

McElvain, C. M. (2010). Transactional literature circles and the reading comprehension of English learners in the mainstream classroom. Journal of Research in Reading, 33(2), 178-205.

Pambianchi, L. C. (2017). Literature circles in a fifth grade classroom: A qualitative study examining how the teacher and students used literature circles and the impact they have on student learning (Unpublished Doctoral dissertation. Mississippi State University, USA.

Pearson, P. D., Cervetti, G. N. ve Tilson, J. L. (2008). Reading for understanding. In L. Darling-Hammond (Ed.), Powerful Learning: What we know about teaching for understanding (pp. 71-111). San Francisco, CA: Jossey-Bass.

Raphael, T.E. ve Au, K.H. (2005) QAR: Enhancing Comprehension and Test Taking Across Grades and Content Areas. The Reading Teacher, 59(3), 206-221. 
Rich, R.Z. \& Blake, S. (1994). Using pictures to assist in comprehension and recall, Intervention inSchool and Clinic, 29, (5) 271-275.

Schoonmaker, R.G. (2014). A blended learning approach to reading circles for English language learners. Second Language Studies, 33(1),1-22

Short, K.G. (1986). Literacy as a collaborative experience. Unpublished doctoral dissertation, Indiana University.

Smith, C., Tracy, E., \& Weber, L. (1998). Motivating independent reading: The route to a lifetime of education. Retrieved from ERIC database. (ED422559).

Tomlinson, C.A. ve Strickland, C.A. (2005). Differentiation in practice: a resource guide for differentiating curriculum, grades 9-12. Alexandria, USA: Association for Supervision and Curriculum Development.

Tracey, D. ve Morrow, L.M. (2012). Lenses on reading: An introduction to theories and models. New York, NY: Guilford Press.

Valencia, S. ve Buly, M. (2004). Behind test scores: What struggling readers really need. The Reading Teacher, 57(6), 520-531.

Vygotsky, L.S. (1978). Mind in society. The development of higher mental processes. Cambridge, MA: Harvard University Press.

Whittingham, J. (2013) Literature circles: A perfect match for online instruction. Tech Trends, 57, 4, 53-58.

Wutz, J.A., \& Wedwick, L. (2005). Bookmatch: Scaffolding book selection book for independent reading. International Reading Association, 16-32.

Yoon, B. (2007). Offering or limiting opportunities: Teachers' roles and approaches to English-language

learners' participation in literacy activities. The Reading Teacher, 61(3), 216-225.

\section{Extended Abstract Introduction}

An important goal of schools is to improve students' cognitive, affective, and social skills. Literature circles is a method that is used to achieve this goal in schools. A variety of different activities related to reading books take place in literature circles. Students who chose the same book get together to form groups. In these groups, students discuss and share what they have read. Students do a variety of activities in literature circles based on their individual roles in the groups. The responsibilities and roles of students in literature circle activities are divided into two as main and optional ones. The main roles are questioner, connector, literary luminary, and illustrator. Optional roles are roles such as summarizer, vocabulary enricher, scene setter, character sketcher, and predictor. Each student in the group assumes a role and does whatever their role requires. While questioner prepares a question list to be discussed, connector forms connections between the book and the world. In other words, connector makes connections between what she/he has read and her/his own experiences, similarities either in different places or at different times. Illustrator draws a picture of what she/he has read. This illustration may be a painting, a drawing, a figure or a graphic. Also, this illustration can be either one of the elements of the story or something that it reminds of. Summarizer summarizes what has been read and she/he focuses on important parts of the story. Literary luminary chooses a paragraph or a sentence to discuss it with her/his group. The aim of this discussion is to extend group members' understanding, by figuring out something funny, powerful, and interesting. Vocabulary enricher looks for the important words in the story. She/he finds unknown words and looks their meanings up in the dictionary. When vocabulary enricher figures out the meanings of words that the students do not know, she/he highlights them. Afterwards, she/he writes them down. Scene setter should know the place where the action occurs in the story and how the scenes where the characters move change in the story. Even if the scene does not change a lot, it is an important part of the story. Scene setter should follow the places where the actions occur in the story. In order to show the places, scene setter uses a dictionary and a map. Character sketcher writes down the features of the characters in the story. Predictor makes predictions about what the students have read. Literature circles, which are related to interactive and transactional reading models and the social constructivism theory, give opportunities to use student-centered methods in classes and contribute to the development of students' higher order thinking skills. 
Implementation of literatures circles consists of certain phases. In the first phase, students who choose the same book get together in groups. The overall group size ranges from 4 to 6 students. In the second phase, group members do role distribution among themselves. After sharing roles, each member starts to work in order to fulfill the responsibilities their roles bring. After a follow-up discussion, every group presents a project about what they have read. The projects may be a drama, a poster, designing a cover for the book, or shooting a short film. In addition, all activities may be shared on the Internet. After the discussion, multiple evaluations are processed. When literature circles are evaluated, formative and summative evaluation procedures are employed. While doing self-evaluation, evaluation of roles, graphic organizers are used in the formative process; multiple-choice tests and open-ended questions are used in the summative process. After completing a literature circle, a new one is started. In the new circles, group members as well as their roles differentiate. This way each student benefits from their different roles in different groups.

\section{Result and Discussion}

Literature circles contribute to students' cognitive, social, and affective skills. As for cognitive contribution, literature circles improve reading comprehension of students since many reading strategies such as questioning and illustrating are used based on the students' roles in the groups. Both of those strategies are important reading strategies in the scholarly literature. Additionally, other roles and their requirements facilitate students' reading comprehension. Also, as connector makes connections between background knowledge and what it is read, this helps students construct meaning in their minds. Discussions in literature circles improve students' higher-order thinking skills. Creative thinking, critical thinking, and reflective thinking skills are improved through literature circles. Given the affective dimension of literature circles, they help students improve their decision making skills and contribute to the students' becoming self-regulated learners. For as long as these skills are improved, students' confidence increases, and they start to choose what they love to read and develop positive attitudes towards reading. As for the social contribution of literature circles, students get together to form groups. In groups, a variety of discussions take place, and students share their ideas. Through mutual collaboration, group members support each other, try to understand each other, and seize the opportunity to see different perspectives. Given the all benefits mentioned above, literature circles provide unique opportunities for teachers who are interested in using student-centered activities in their classrooms. 